\title{
Erratum to: Localization, Hybridization, and Coupling of Plasmon Resonances in an Aluminum Nanomatryushka
}

\author{
Arash Ahmadivand • Nezih Pala
}

Published online: 25 February 2015

(C) Springer Science+Business Media New York 2015

\section{Erratum to: Plasmonics}

DOI 10.1007/s11468-014-9868-Z

In the original version of this paper, reference \#32 is incorrect.

The correct version:

32. A. Ahmadivand, S. Golmohammadi, and A. Rostami, Broad comparison between Au nanospheres, nanorods and nanorings as an S-bend plasmon waveguide at optical Cband spectrum, J. Opt. Technol., 80, 80-87, 2013.

The online version of the original article can be found at http://dx.doi.org/ 10.1007/s11468-014-9868-z.

\footnotetext{
A. Ahmadivand $(\square) \cdot$ N. Pala Department of Electrical and Computer Engineering, Florida International University, 10555 W Flagler St.,

Miami, FL 33174, USA

e-mail: aahma011@fiu.edu
} 